\title{
Takács Flóra
}

\section{Egy pszıchıátrıa intézet válaszaı a késô modern kor kıhívásaıra}

Az elmúlt évtizedekben sok szempontból átalakult a társadalmunk, aminek egyik következménye, hogy a különféle intézmények társadalmi szerepe és a cselekvőkhöz füződő viszonya is sok tekintetben megváltozott a korábbiakhoz képest. A késő modern társadalmakban a hagyományos, klasszikus modernitásra jellemző társadalmi struktúra felbomlott, az egyének társadalmi helyzete és identitáskonstrukciója megváltozott, az egymás és az intézmények iránti bizalom mértéke csökkent, újfajta kockázatok és a hatalomgyakorlás eddig nem ismert formái jelentek meg. Ezen társadalmi változások hatására az intézmények veszítettek stabilitásukból, és egyre inkább rákényszerülnek arra, hogy konzervatív működésmódjukon, struktúrájukon változtassanak és a velük kapcsolatban álló egyének elvárásaira rugalmasan reagáljanak. Ezen folyamatok következtében az intézményekről alkotott tudományos felfogás is módosult, új elemekkel egészült ki, úgymint diskurzív institucionalizmus (Szalay 2011; Dimaggio és Powell) vagy Anthony Giddens „strukturációs” elmélete (Giddens 1984). A hagyományos intézményelméletek kiindulópontja a struktúra elsődlegessége, mely a cselekvők mozgásterét korlátozza, befolyásolja. A fent említett változások hatására azonban az intézményekkel foglalkozó elméletek is elmozdultak abba az irányba, hogy az intézményeket ne csupán az egyének cselekvési lehetőségeit korlátozó tényezőkként, hanem a társadalmi struktúra olyan dinamikusan változó részeként értelmezzék, melyre a cselekvők egyéni értékeik és érdekeik mentén képesek hatást gyakorolni, müködésüket képesek viselkedésükkel, kommunikációjukkal alakítani. Ezek az elméletek kétoldalú kapcsolatot tételeznek fel az egyének és az intézmények között, vagyis nem a szilárd struktúra (melynek kikristályosult formái az intézmények) hat kizárólag kényszerítő erővel az egyének cselekvéseire, hanem kölcsönösen képesek egymást korlátozni, befolyásolni. Ezen újfajta intézményi felfogás a szociológiában eddig többnyire elméleti síkon fogalmazódott meg a hagyományos institucionalista elméletek kritikájaként, illetve a késő modernitás problémáit feltáró modernitáselméletek részeként, azonban kevés empirikus kutatás készült ezekből kiindulva, melyek a konkrét esetekben képesek lennének feltárni, hogy milyen tényezők hatására változik vagy marad stabil egy intézmény. 
Tanulmányomban egy olyan esettanulmányokon alapuló kvalitatív módszertani eszközt mutatok be, melynek elméleti kerete a hagyományos institucionalista felfogástól eltér, és melynek segítségével a konkrét intézmények és intézménytípusok fejlődési, változási útját lehet vizsgálni a késő modernitásra jellemző jegyeket hordozó társadalmi közegben.

Választ keresek arra a kérdésre, hogy egy konkrét intézmény milyen alkalmazkodási stratégiákat követhet vagy milyen müködésmódokat alakíthat ki, melyek a változó társadalmi feltételrendszer keretei között elősegítik az alkalmazkodását, vagy ha e téren kudarcot vall, milyen típusú patologikus vagy diszfunkcionális válaszok rögzülhetnek. Azt is szeretném megérteni, hogy időben ezek a müködési mintázatok hogyan és milyen erők hatására alakulnak ki vagy változnak meg, illetve milyen szereplők játszhatnak szerepet a változásokban. Kutatásomban egy bentlakásos pszichiátriai intézetet, a Szentgotthárdi Pszichiátriai Betegek Otthonát vizsgáltam, ami egyfajta módszertani és elméleti kísérletnek tekinthető.

\section{Az intézmények szerepe a modernitáselméletek tükrében}

A szociológia történetében a pszichiátriát többféle elméleti keret alapján kutatták. Korábban Michel Foucault a hatalom müködésének, vagy Erving Goffman a totális intézmények müködésének perspektívájából írtál le, hogy a bolondság hogyan konstruálódik, illetve hogyan manifesztálódik ez a folyamat a pszichiátriák mindennapi működésmódjában, szerkezetében. Foucault a hatalom mikrovilágának elnyomó folyamatait kívánta feltárni és a különféle rejtett uralmi-függőségi viszonyokat helyezte vizsgálódásának fókuszába. A totális intézmények (ezen belül a pszichiátriák is) a megfigyelés és a kontroll gyakorlásának elsődleges terepeiként funkcionálnak, így rajtuk keresztül vizsgálta Foucault, hogyan jön létre és működik a modernitásra jellemző fegyelmi rend a kliensekkel való bánásmódon keresztül (Foucault 2004). Goffman szociálpszichológusként résztvevő megfigyeléses módszerrel kutatta a totális intézmények, többek között a pszichiátriák belső müködését, gyakorlatait és az ott lezajló interakciókat, eredményeivel végső soron alátámasztva Foucault elméleti megállapításait (Goffman 1974). Az alábbiakban ezen elméletektől egy lépéssel hátra lépve, más elméleti konstrukció mentén kívánom vizsgálni a pszichiátriát, jobban a középpontba helyezve a késő modern társadalmakra jellemző kihívásokat, társadalmi problémákat. A felügyelet kérdése ebben az elméleti keretben is releváns probléma a késő modernitásra jellemző új, rejtett felügyeleti formák lehetséges megjelenése okán, azonban az intézményeket nem kizárólag a hatalom és a felügyelet perspektívájából közelítem meg. ${ }^{1}$

A késő modernitással foglalkozó társadalomelméletek többek között arra a kérdésre keresik a választ, hogy az új társadalmi kor olyan kihívásaira, mint az ontológiai bizonytalanság, a kockázattársadalom, vagy a szakértői tudással szembeni bizalmatlanság, milyen válaszokat tudnak adni az egyének és a velük kapcsolatban álló intézmények. A megváltozott társadalmi környezetben, ahol a hagyományos modernitás makrostruktúrái felbomlanak és új kockázatok jelennek meg, az egyének és az intézmények közötti interakció megváltozásá-

1 Jelen tanulmányban ezt a dimenziót nem tárgyalom, mivel Anthony Giddens elméletét helyezem vizsgálódásaim fókuszába, mely elmélet a felügyelet problémáját nem érinti, azonban szakdolgozatomban erre is kitérek (Takács 2017). 
nak köszönhetően az intézmények maguk is átalakulnak. Az elméletek nagy része föként az egyént helyezi a vizsgálódása fókuszába, de vannak köztük olyanok is, melyek a késő modernitás jegyeit mutató társadalmak intézményeinek problematikáját is hangsúlyosan tárgyalják. Gondolok itt többek között az olyan angolszász és francia elméletekre, mint Anthony Giddens társadalomelméleti munkássága (Giddens 1990, 1984), Francois Dubet elmélete az intézményes program hanyatlásáról (Dubet 2002), Dominique Memmi diszkurzív felügyeletről alkotott elképzelése (Memmi 2012), vagy Luc Boltanski intézményi változásról szóló elmélete (Boltanski és Chiapello 1999). Ezen elméletek arra keresik a választ, hogy az egyének milyen interakcióban állnak az intézményekkel, és a közöttük oda-vissza ható folyamatok során hogyan formálódnak, illetve ezek a változások milyen hatással vannak szélesebben vett társadalmi folyamatokra.

A különféle elméletek különböző pontokra helyezik a hangsúlyt, de közös bennük, hogy az intézményeket is olyan társadalmi szereplöknek tekintik, melyeket érint a késő modernitás válsága abban a tekintetben, hogy a hagyományos formáik, müködési elveik, az egyénekkel fenntartott kapcsolataik és az instrumentális racionalitáshoz való viszonyuk átalakulóban van a társadalom különféle válságtüneteire adott reakcióiknak köszönhetően. Azt azonban szem elött kell tartanunk, hogy a fent említett változások és válságtüntetek nem általános jellegüek, nem vonatkoznak a társadalom minden szegmensére ugyanabban a mértékben, hanem folyamatos változásnak, átalakulásnak lehetünk szemtanúi. Ennek fényében egy empirikus kutatásban lényeges szempont lehet az is, hogy megvizsgáljuk, milyen mértékben és hogyan keverednek egymással a premodern, modern és késő modern integrációs logika elemei az adott társadalmi jelenség vagy intézmény tekintetében. Ezért fontos, hogy a konkrét intézmény müködését több elmélet fényében, és amennyire a kutatás engedi, időbeli változásaival együtt tárjuk fel. Értelmezésem szerint az egyének és intézmények által adható potenciális reakciók két ideáltipikus állapot között egy elképzelt skálán helyezkednek el, attól függően, hogy a változásokra adott válaszaik - Anthony Giddens fogalmaival élve - inkább „emancipatorikusnak” vagy inkább „patologikusnak” tekinthetok-e (Giddens 1984). Ezen megközelítés szerint emancipatorikusnak nevezzük azokat a válaszokat, melyek egyfajta pozitív megbirkózási stratégiát segítenek elő, patologikusnak pedig azokat, melyek diszfunkcionális pályán tartják az egyének vagy az adott intézmény fejlődési ívét és cselekvési lehetőségeit.

A modernitáselméletek tágabb elméleti horizontot jelölnek ki azzal a nem titkolt céllal, hogy empirikus kutatások számára nyújtsanak értelmezési keretet. Ennek ellenére azonban gyakorlati kutatásokkal ritkán kapcsolódnak össze, föleg, ha az intézmények vizsgálatára gondolunk. Az általam készített esettanulmánnyal egy lehetséges módját mutatom be annak, hogyan lehet empirikusan kutatni intézményeket a késő modernitás jellemzőit mutató társadalmakban. Tanulmányom középpontjába a fent említett modernitáselméletek közül Anthony Giddens intézmények müködésére és a cselekvői perspektívák értelmezésére vonatkozó elméletét helyezem, és az ezen elméleti keretből levezetett dimenziók mentén elemzem a konkrét intézmény müködését. A kutatás egyfelöl módszertani lehetőségeket nyújt a modernitáselméletek empirikus teszteléséhez, másfelöl eredményeivel hozzájárulni kíván a rendszerváltás utáni szociális intézményrendszer működésének mélyebb megértéshez és potenciális fejlődési lehetőségeinek feltárásához. 


\section{Giddens modernitáselmélete és a reflexív intézmények társadalmi szerepe}

Giddens sok munkájában foglalkozik a késő modernitás problémakörével, ezen belül többek között az intézmények lehetséges szerepével is. Tanulmányomban az ő elméleteihez kapcsolódva alakítottam ki azokat a dimenziókat, melyek mentén a szentgotthárdi pszichiátriai intézet működését tártam fel. Hangsúlyozni szeretném azonban, hogy ezek a dimenziók csak egy metszetét alkotják a bevonható dimenzióknak, illetve Giddens mellett olyan más szerzőket is meg lehetne említeni a késő modernitás és a reflexív intézmények problematikája kapcsán, mint Ulrich Beck (2003 [1986]), aki a „reflexív modernitás” és a „kockázattársadalom” problémáját járja körül műveiben, vagy Manuel Castells (1996), aki a „hálózati társadalom” és ezen belül a különféle mozgalmak kialakulásáról ír, azonban Beck és Castells Giddensszel sok helyen nagyon hasonló következtetésekre jutva inkább a globális változásokra és mozgalmakra, és nem a konkrét intézmények müködésére fókuszálnak. Anthony Giddens elmélete mellett több, az intézmények müködésével kapcsolatos modernitáselmélet létezik, melyek alapján más dimenziókat is ki lehet alakítani, többek között a büntetési-felügyeleti rezsimmel és a szervezet belső müködésével kapcsolatban. A dimenziók kibővítése azonban jelen tanulmány terjedelmi kereteit szétfeszítené, így inkább arra törekedtem, hogy korlátozott számú dimenzióra redukáljam a vizsgálódásomat, mely irány viszont mélyebb és nagyobb részletgazdagságú megértést tesz lehetővé.

Giddens társadalomelméleti megközelítése a társadalmi változásokat a cselekvők és az intézmények folyamatos interakciójaként értelmezi. Ezt az állandóan jelen levő kölcsönhatásokból felépülő folyamatot „strukturációnak” nevezi, mely mozgatórugója a cselekvők ontológiai biztonság iránti tudatalatti vágya, vagyis az az igény, hogy otthonosan érezzék magukat a világban (Sik 2013; Giddens 1984). Mivel a késő modern társadalmakban megszaporodtak az olyan bizonytalanságot okozó kockázatok, melyeket nem tudnak hagyományos módokon kontrollálni az egyének, a cselekvőknek olyan újfajta rutinokat kell kialakítaniuk, melyek mentén ismét stabilizálódhat a cselekvéskoordinációjuk. Ezen rutinok mentén a cselekvők képesek lesznek kalkulálni egymás viselkedését, cselekedeteit az adott helyzetekben, ezzel csökkentve a különféle kockázatokat. Ezek a rutinok akkor tudnak megfelelően működni, ha az egyének reflexívvé válnak. Ez a két, egymással ellentétes irányú hatás, a stabilizálódó rutinok és a cselekvők reflexivitása, eredményezi a cselekvők és intézmények között folyamatosan fennálló kölcsönhatást (Giddens 1984; Sik 2013). Giddens szerint a késő modernitásban a racionalitásban gyökerező tradíciókba, illetve a szakértői tudásokba vetett bizalom megrendül, így azok folyamatos igazolásra szorulnak. Korábban az intézmények müködése alapjául szolgáló szakértői tudást nem vonták kétségbe, legitimként fogadták el a cselekvők. Ezzel szemben a késő modernitás korában az intézmények arra kényszerülnek, hogy reflexív módon interakcióba lépjenek az egyénekkel, reagáljanak az igényeikre, problémáikra, és ezen keresztül folyamatosan igazolják legitimitásuk alapjait. Az új kihívások hatására a cselekvők, az intézmények, és a köztük lévő interakció is megváltozik.

A fent felvázolt folyamatnak a következménye a "generatív politika” megjelenése is, mely szerint a politikai döntéshozók a cselekvők reflexív működésmódjának figyelembevételével hoznak döntéseket: 
Amit tehetnek, az nem más, mint hogy belátják, a politika csupán egy a cselekvő által figyelembe vett szakértői rendszerek közül, így a politikusoknak csupán arra van lehetőségük, hogy reflexió, vagyis a kockázatbecslő kalkulusok szintjén próbálnak meg hatást kiváltani. Ebbe egyaránt beletartozik a szakértelemhez való hozzáférés feltételeinek megteremtése, a cselekvési alternatívák terének kitágítása, az autonómia és a reflexivitás fejlesztése, a politikai legitimitás decentralizált döntési mechanizmusokhoz való hozzákapcsolása. Ezt a cselekvők reflexív autonómiáját nem csupán tiszteletben tartó, de egyenesen arra építö, a direkt utasítás helyett a kívánt hatás cselekvők általi létrehozásának előfeltételeire irányuló eljárást nevezzük „generatív politikának” (Sik 2013: 108).

A generatív politika megszilárdulásához demokratizálni kell a demokráciát, és dialogikus lehetőségeket kell teremteni a cselekvők között annak érdekében, hogy a reflexív müködésmód széles körben teret tudjon nyerni. Ez a demokratizálódási folyamat végbemehet az intim kapcsolatokban - vagyis a családban - és a „tiszta kapcsolatokban”2 (Giddens 1991), a civil szervezetek és mozgalmak tevékenységének köszönhetően, vagy olyan formális szervezetekben, mint a munkahelyek. A dialogikusság elvének elterjedése az intézmények reflexív potenciálját és nyitottságát növeli, illetve ezzel párhuzamosan csökkenti a cselekvők intézmények iránti bizalmatlanságát. Azokban az intézményekben tud a dialogikusság elve elterjedni, ahol uralommentes a kommunikáció, a szervezeti működés átlátható, ellenőrizhetöek a folyamatok, illetve a demokratizálódás színtereiben egyenlőség van a felek között, és így azok autonóm cselekvőként tudnak fellépni az interakciós helyzetekben.

A fenti elméletek mentén két ideáltipikus fajtája létezik a késő modern társadalmak jelenségeire, kihívásaira reagáló intézményeknek. Egyfelől reagálhatnak „emancipatorikus”, adaptív módon, úgy, hogy az egyének reflexív képességének, autonómiájának növekedését követően ők maguk is reflexívebbekké, nyitottabbakká válnak, figyelembe veszik a velük interakcióba lépő egyének véleményét, szándékait. Az ilyen intézmények kevésbé hierarchikusak, demokratikusabbak, nyitottabbak, nagyobb teret hagynak az egyének autonómiatörekvéseinek, megteremtik a kritika feltételeit, átláthatók, ellenőrizhetők, jellemző rájuk a generatív politika és a kétirányú, partneri kommunikáció az egyénekkel, illetve más velük kapcsolatban álló intézményekkel. Ezzel szemben a spektrum másik végpontján azok a „patologikusan" reagáló szervezetek állnak, melyek ragaszkodnak a hierarchikus felépítéshez, más cselekvőket nem kezelnek egyenrangú félként, a felügyelet és kontroll új formáit alkalmazzák, az egyénekre hárítják döntéseik felelősségét, a szakértői hatalmi pozícióikat akár erővel is meg kívánják őrizni, müködésük ellenőrizhetetlen, átláthatatlan, zárt, nincs tere bennük a kritikának. A valós intézményekben egyszerre találhatók meg az emancipatorikus és patologikus vonások, és időben változik az összetételük struktúrája. Tanulmányomban azt vizsgálom, hogy a különböző elméleti dimenziók mentén a konkrét vizsgált intézmény melyik ideáltipikus pólus felé közelít inkább; időben milyen irányban mozdul el a müködése, ha elmozdul; és a cselekvési terét milyen hatások befolyásolták eközben.

2 Giddens tiszta kapcsolatnak nevezi azokat az újfajta, a késő modernitás korában nagyobb arányban elterjedő kapcsolatokat, melyek mély érzelmeken nyugvó, közeli, informális, nem intézményi keretek vagy tradíciók által meghatározott emberi kapcsolatok. Ezek a tiszta kapcsolatok az egyének által sokkal rugalmasabban, könnyebben alakíthatók, mint más kapcsolatok, ezért azonban gyakran törékenyebbek, sérülékenyebbek is. Az egyensúlyuk az egyének reflexív és kommunikatív képességei segítségével garantálható. Giddens elképzelése szerint ezen kapcsolatok révén lehet képes az egyén a környezetébe, a társdalomba vetett bizalmát visszanyerni, így fontos szerepet játszanak a késő modern társadalmak stabilitásának fenntartásában is. 


\section{A vizsgálat alapjául szolgáló elméleti dimenziók}

Annak érdekében, hogy Giddens elméletét a gyakorlatban is alkalmazni lehessen egy konkrét intézmény vizsgálatakor, az elméletből levezetve négy elkülönülő dimenziót alakítottam ki, melyek az intézmény működését érintik. Ezek a dimenziók valamennyire összefüggenek egymással, de az elmélet különböző területeit írják le. Először megvizsgáltam, hogy a különböző cselekvőkkel milyen módon kommunikál az intézmény, másodsorban azt, hogy mennyire tekinthető reflexívnek a szervezeti forma, harmadrészt a reflexív cselekvési tér kiszámíthatóságát, végül pedig a progresszív gyakorlatok és reformok adaptálásának képességét vizsgáltam.

A cselekvőkkel folytatott kommunikáció dimenziójában áttekintem, hogy az intézmény milyen módokon lép interakcióba, hogyan kommunikál más intézményekkel, illetve a nyilvánosságban az intézményről véleményt formáló különféle aktorokkal. Giddens elképzelése szerint a reflexív intézményi mủködésmód kialakulásának alapfeltétele a cselekvőkkel folytatott folyamatos kommunikáció, melynek során vissza tudja állítani az intézmény a szakértői tudásba, illetve az intézménybe magába vetett bizalmat. Ehhez azonban szükséges előfeltétel, hogy adott intézmény biztosítsa a kommunikáció feltételeit, különféle csatornáit, másrészt ezeken keresztül valós, egyenrangú, kétirányú kommunikációs kapcsolatot létesítsen a cselekvőkkel. A kommunikációval összefüggésben vizsgálom azt is, hogy a nyilvánosság különféle szereplőivel, a betegek érdekeit védő hozzátartozókkal, érdekvédő szervezetekkel, a fenntartóval és a minisztériummal, illetve a városban található más intézményekkel milyen kapcsolatban áll az intézmény, milyen mértékben hallgatják meg a véleményüket, és ezek hatására mennyire nyitottak a saját működésmódjuk megváltoztatására. Emellett fontos vizsgálandó szempont az intézmény átláthatósága és számonkérhetősége is.

A második dimenzióban azt igyekszem feltárni, hogy az intézmény belsö müködése menynyire reflexív, a kritika feltételeit mennyire tudja biztosítani a szervezeti formája. Ahhoz, hogy Giddens elmélete szerint az intézet emancipatorikus válaszokat tudjon adni a késő modern társadalmak problémáira és reflexívvé tudjon válni, arra van szükség, hogy a belső működése demokratikus legyen, a cselekvőket egyenrangú partnerként kezelje, az információk terjedését biztosítani tudja, átlátható és ellenőrizhető legyen a müködése, a belső hierarchiákat igyekezzen minél jobban lebontani, decentralizálni a müködését, illetve felületeket biztosítson a vélemények kifejtéséhez, a kritikák artikulálásához, a dolgozók és lakók érdekeinek érvényesítéséhez. Ebben a fejezetben azt is vizsgálom, hogy az intézet, mint formális szervezet, mennyire tud a generatív politika bázisa lenni, mennyire érvényesül müködésében a dialogikusság elve és a demokratizálódás folyamata. A szervezet müködésének vizsgálatakor kettéválasztom a lakók, illetve a dolgozók intézményen belüli helyzetét, lehetőségeit, illetve külön tárgyalom a formális érdekérvényesítő fórumok működését mind a két csoport esetében.

A harmadik kialakított dimenzió a reflexív cselekvési tér kiszámíthatósága, ahol arra keresem a választ, hogy az intézet a saját cselekvési szférájának logikáján belül mennyire müködik racionálisan, rutinszerủen, reflexíven, elősegítve ezzel az ontológiai biztonság kialakulását a vele kapcsolatban álló egyénekben, vagy mennyire írják felül más szférák cselekvési logikáinak torzító hatásai a müködési elveit, ezáltal növelve a bizonytalanságot a vele kapcsolatban álló cselekvőkben. Elvi szinten a jogalkotó arra törekedett, hogy olyan feltételeket, müködési környezetet teremtsen, mely a szakmai semlegesség, az átláthatóság és az egyenlőség elveinek érvényesülését segíti elő, vagyis az adott szféra autonóm müködésének felté- 
telrendszerét, ez azonban a valóságban nem minden esetben érvényesül. Potenciális torzító tényezőként vettem számba a szociális ágazat, a politikai érdekek és jogszabályi környezet, a fenntartó müködésének és a személyes érdekeknek lehetséges torzító hatásait, illetve a rendszer tehetetlenségét. Ebben a dimenzióban kerül terítékre az intézmény autonóm müködésének kérdése, melyre a fenti tényezők hatásainak áttekintése ad választ.

A negyedik, és egyben utolsó dimenzióban azt igyekszem feltárni, hogy az intézmény mennyire szándékozik és mennyire képes progresszív gyakorlatokat, reformokat adaptálni, beépíteni a müködésébe. Giddens elmélete szerint a késő modernitásban megingott a bizalom a hagyományos szakértői tudásokban, ezért az intézményeknek újra és újra legitimálniuk kell a hatalmukat, amit azzal tudnak elősegíteni, hogy reflexívvé válnak. Ezen folyamatok hatására az intézmények arra kényszerülnek, hogy a hagyományos szakértői tudások mellett a korábbiaknál nagyobb sebességgel és lényegesen több más szakterületről érkező új tudáselemet építsenek be tudáskészletükbe és müködésükbe. A pszichiátria területén is sokféle olyan, a hagyományos felfogástól eltérő szakmai irányzat, müködésmód jelent meg az elmúlt évtizedekben, melyek adaptálására kényszerülhet az intézmény. Kérdés az, hogy a rendszerben múködő autoritásközpontok mennyire igyekeznek megvédeni a hagyományos szakértői tudásokat, illetve az intézmény milyen módon vesz részt ebben a folyamatban, mennyire képes új módszereket beépíteni a müködésébe, vagy mennyire merevedik meg a kritika hatására és zárkózik be. Ebben a dimenzióban három aldimenzió alá rendeztem a különféle progresszív gyakorlatokat. Az első aldimenzió a szervezeti működést és a működési szabályokat érintő újításokat foglalja magába, a második a kitagolás, intézménytelenítés és integráció átalakulásait, míg a harmadik a progresszív pszichiátriai gyakorlatokat és a belső képzéssel kapcsolatos változásokat.

\section{Késő modern intézményi jellemzők a pszichiátriai ellátórendszerben és a magyar társadalmi környezet sajátosságai}

A magyar pszichiátriai ellátórendszer az 1950-es években alapvetően a nagyméretü zárt, bentlakásos pszichiátriai szociális otthonokra épült, ahol az ápolás-gondozási tevékenység és a gyógyszeres kezelések domináltak. Ezeket az intézményeket az állam tartotta fenn azt a tudatos stratégiát alkalmazva, hogy elzárják, láthatatlanná tegyék a pszichiátriai betegeket a többségi a társadalom számára, mivel közveszélyes, deviáns elemekként tekintettek rájuk. Müködésükre jellemző a túlbürokratizáltság, a szigorú szabályrendszerek és büntetési rezsim, az ellátottak emberi jogainak rendszeres megsértése, illetve az üzemszerűség. Ez az intézménytípus az államszocializmus domináns ellátási formájaként harmonizált a politikai rendszer alapvető müködési logikájával (Légmán 2011). 1952-ben a Fővárosi Tanács által alapított Szentgotthárdi Pszichiátriai Betegek Otthona is ilyen intézményként nyitotta meg a kapuit.

Az 1960-as évek elejétől kezdve folyamatosan elterjedt az antipszichiátria irányzata, illetve az a pszichiátriai nézet, miszerint a pszichiátriai betegségek epizodikus jellegüek és nem idővel romló természetűek, így a pszichiátriák a foucault-i értelemben vett fegyelmező intézmény helyett elkezdtek egészségügyi szolgáltatássá válni (Légmán 2011). Ezzel a változással megjelent Magyarországon a bentlakásos intézménytípussal párhuzamosan a forgóajtós intézményi modell, mely nagyobb mértékben támaszkodik különféle közösségi erőforrásokra, és igyekszik a saját környezetükben tartani a betegeket akut kórházi osztályok segítségével. 
Ebben a modellben is a gyógyszeres kezelés a domináns terápiás forma, illetve az állam a fenntartója az intézményi hálózatnak, viszont nem cél, hogy láthatatlanná tegyék a betegeket a társadalom számára - a betegek nem szakadnak el a környezetüktől, adott esetben családi és baráti támogató közegükre is tudnak támaszkodni az ellátórendszeren kívül. Azonban ennek az ellátási formának is számos gyenge pontja van, többek között az, hogy önmagában nem segíti a betegek társadalmi reintegrációját (Bányai és Légmán 2009).

Magyarországon az államszocializmus idején a reflexivitásnak nem volt érdemi tere a cselekvők tömegei és az intézmények közötti interakciókban, köszönhetően az akkori rendszer autoriter, antidemokratikus, felülről lefelé szerveződő, centralizált müködésmódjának és a politikai mező dominanciájának. A rendszerváltás előtti időszakban az intézményi környezetre jellemző volt, hogy az alrendszerek hierarchikus viszonyban álltak egymással, a szakmai és gazdasági döntések alárendelődtek a politikai döntéseknek. A tervgazdaság és a centralizált politikai irányítás azt eredményezte, hogy az intézmények működését elsősorban nem racionális, szakmai szempontok, hanem politikai és személyes érdekek befolyásolták.

A rendszerváltást követően a nyilvánosságbeli diskurzusok lehetőségei kiszélesedtek, és a késő modernitásra jellemző globális jelenségek fokozatosan teret nyertek a Nyugathoz egyre több szálon kapcsolódó Magyarországon. Ezen folyamatoknak köszönhetően tér nyílt a reflexív működésmód kialakulására mind az egyének, mind ezzel összefüggésben az intézmények szintjén. A reflexivitás képessége azonban Magyarországon csak kis szigetekben alakult ki. A magyar társadalom erősen bizalmatlan a különféle közintézményekkel szemben, ami egyfajta reflexív potenciált jelez (Boda és Medve 2012). Ezzel párhuzamosan azonban megmaradtak a korábbi rendszerből átörökölt viselkedésminták - az emberek inkább az állami gondoskodásban bíznak, nem a civil kontrollban -, így az autonóm cselekvés lehetőségei korlátozottak maradtak, és nem alakultak ki a kontroll demokratikus országokból jól ismert formái (Arató és Nizák 2012). Az intézményrendszer müködését továbbra is erősen torzítják az előző rendszerből hozott olyan patologikus müködtetési mechanizmusok, mint a nepotizmus, a korrupció, vagy a személyes kapcsolati hálókon keresztül kötött különalkuk. A kockázatok kontrollálásába nem tudnak bevonódni elég nagy mértékben az egyéni cselekvők és az érdekeiket a nyilvánosságban artikulálni képes civil szféra. A reflexivitás tere korlátozott marad, a közérdek sokszor továbbra sem tud előtérbe kerülni az egyéni érdekekkel szemben a döntések meghozatalkor.

A pszichiátriai intézményrendszerben a rendszerváltás után, az 1990-es évek közepétől Magyarországon is meghonosodtak a külföldön széles körben elterjedt közösségi ellátási formák a nagy méretü bentlakásos intézményekkel és a forgóajtós modellel párhuzamosan. A nappali-közösségi ellátás alapvetően a beteg családi környezetében és klubokban zajlik. Ez az ellátási forma teszi a leginkább lehetővé, hogy a pszichiátriai betegséggel küzdők a társadalom integrált részei maradjanak. Egyfelől a betegek nem kizárólag gyógyszeres kezelést kapnak, hanem többféle alternatív terápián vesznek részt, másfelől kezelésük részleteit nem kizárólag a pszichiáter határozza meg, hanem az egyén és az egyén környezetének a bevonásával alakítják ki egyéni gondozási tervüket. Míg az első két ellátási forma esetében a beteg nem tud részt venni munkavállalóként a munkaerőpiacon, ennél a modellnél cél, hogy a betegek vagy védett munkahelyeken, vagy állapotuktól függően a nyílt munkaerőpiacon tudjanak munkát vállalni. Hazánkban jelenleg ugyan létezik ez az ellátási forma, de kisebbségben vannak az ilyen típusú ellátást lehetővé tevő intézmények, és a forgóajtós modell maradt a domináns ellátási forma. A szociális és pszichiátriai ellátórendszer esetében az 
intézményrendszer alapvetően állami fenntartásban maradt a rendszerváltás után is, nem szaporodtak el a civil szervezetek adományaiból vagy magánforrásokból fenntartott intézmények. Napjainkban is csak szórványosan találhatunk ilyen kezdeményezéseket. Ráadásul a pszichiátriai ellátást jelenleg egymással párhuzamosan végzi az egészségügyi és a szociális szféra, ami sok súrlódásra ad okot, és a rendszer ennek következtében nem képes megfelelö hatékonysággal működni (Légmán 2011).

Visszatekintve az elmúlt több mint fél évszázadra, megfigyelhető az a tendencia, hogy a zárt, bentlakásos intézmények helyét az 1960-as évektől kezdve lassan átvették a nyitottabb, társadalmi integrációt lehetővé tevő ellátási formák. A rendszerváltás után sokan a pszichiátriai ellátórendszer gyökeresen átalakulásában reménykedtek, de a nagy léptékű intézményrendszeri átalakulás elmaradt. Szakmai körökben nagy várakozás előzte meg, hogy beinduljon a bentlakásos szociális otthonok nyitottabbá tétele, a modernizáció, illetve az intézménytelenítés-kitagolás folyamata, melynek során a nagy bentlakásos intézményeket kisebb, a lakók számára élhetőbb, nyitottabb, kisebb létszámú egységekre bontják szét. Az intézménytelenítés folyamata érdemben nem indult el, nem következett be alapvető szemléletváltozás, nem terjedt el a közösségi ellátási modell, és sok tekintetben a szocializmusból megörökölt patologikus intézményi működési formák és viselkedésmódok élnek tovább napjainkig (Bányai és Légmán 2009). Légmán Anna diagnózisa szerint külön problémás a rendszer müködésével kapcsolatban, hogy egyfelöl a közösségi ellátási forma még ott sem képes önállóságra szert tenni, ahol huzamosabb ideje működik, csupán a forgóajtós modell kvázi részeként van jelen, így nem képes tartós szemléletváltozást elindítani az ellátórendszeren belül. Másfelől a lakóotthonok is hasonlóan önállótlanok és alárendeltek, mivel számszerüen kevés van belőlük, és ahol léteznek, ott is a nagy intézmények hozták létre őket azzal a céllal, hogy csökkentésék a zsúfoltságot vagy jutalmazási eszközként használják. Ezek a folyamatok így nem a változás lehetőségét segítik elö, hanem a fennálló helyzetet konzerválják (Légmán 2011).

A nyilvánosság és a reflexivitás lehetőségének oldaláról vizsgálva az intézményrendszert, azt láthatjuk, hogy a civil kontroll és a nyilvánosság nem tett szert akkora jelentőségre, hogy valós ellenőrzést tudjon az intézményrendszer fölött gyakorolni. A törvények ugyan garantálnak olyan fórumokat, ahol az érintettek meg tudnák védeni a jogaikat, ezek azonban egyrészt nem mindenki számára elérhetőek és nem generálnak intézményi szintü szerkezeti változásokat, másrészt a nyilvánosságban nem kapnak elég teret a felmerülő visszásságok, így a nyomásgyakorlás nem éri el azt a szintet, ami kritikusnak nevezhető. A reflexivitást lehetővé tevő kommunikatív helyzetek továbbra is nehezen tudnak kialakulni, az érintett csoportok gyakran nem tudnak kellő mértékben a nyilvánosságban megjelenni, a problémájuk közügyként való kommunikálására pedig nagyon kis esélyük van.

Mindeközben a pszichiátria mint tudományterület is változóban van. A korábbi, alapvetően orvosi-biológiai pszichiátriai szemléletet sok helyen felváltotta a biopszichoszociális ${ }^{3}$ szemléletmód. A biológiai szemlélet szerint a pszichés betegségek oka alapvetően valamilyen kémiai vagy fizikai agyi elváltozás, melyet gyógyszerekkel kell kezelni. A biopszichoszociláis szemlélet képviselői ezzel szemben azt vallják, hogy a betegségek kiváltó oka nem csupán

3 A „biopszichoszociális” orvosi szemlélet fogalmát George Engel amerikai pszichiáter vezette be az 1970-es években. Engel az akkor uralkodó biomedikális orvosi felfogást kritizálva javasolta ezen új szemléletmód elterjesztését, mely nem kizárólag a biológiai meghatározottságokat, hanem a társadalmi és lelki tényezőket is figyelembe veszi, és ennek megfelelően javasol egyéni élethelyzetekre szabott terápiákat (Engel 1977). 
egy neurológiai-kémiai-biológiai defektus, hanem az egyén és a társadalmi környezetének nem megfelelő illeszkedése. Ebből a szemléletből következik az is, hogy alapvetően nem gyógyszerekkel igyekeznek a pszichiátriai betegségeket kezelni, hanem komplex terápiákkal, melyeknek része az egyén környezetének, potenciálisan támogató szociális kapcsolatainak a bevonása a terápiás folyamatba (Ozsváth 2012). A biopszichoszociális szemlélet elterjedésének hatására egyre inkább előtérbe kerülnek az alternatív terápiás módszerek, céllá válik a betegek társadalmi reintegrációja, a szociális kapcsolati hálójuk fenntartása, a gyógyszeres kezelések átalakulnak, veszítenek terápián belüli korábbi domináns súlyukból.

A rendszerváltás utáni időszakban a segítő szakmák elkezdtek professzionalizálódni, aminek következtében a szociális és egészségügyi szakmában dolgozók számára az elvek szintjén felértékelődött a kliensek és segítők közötti interakció fontossága és a betegekkel kialakított egyenlőbb, partneribb viszony. A valóságban azonban az állami egészségügy és a szociális szféra területén sok esetben azt tapasztalhatjuk, hogy ezek a hierarchikus viszonyok ugyanúgy túlélték sok helyen az előző rendszert, mint sok más attitűd, viselkedésminta. A betegeket sok helyen még mindig alárendelt felekként kezelik, nem vonják be sem őket, sem a környezetüket a róluk szóló döntésekbe (Málovics, Vajda és Kuba 2009), az orvosok között pedig a szigorúan hierarchikus munkamódszer dominál, nem nyert teret a „teammunka” és az egyenrangú kapcsolatokon alapuló kooperáció (Hámornik, Juhász és Vén 2015).

Azt, hogy mennyire jellemző a reflexív intézményi gyakorlat egy adott szektorban vagy intézményben, vizsgálhatjuk egyfelől a jogszabályok, írott dokumentumok, szabályzatok oldaláról, másfelől a különféle cselekvők, aktorok véleményének, gyakorlati cselekvésének elemzésével. Az elemzés során fontos lehet megfigyelni, hogy az írott dokumentumokban található tartalom milyen kapcsolatban áll a valóságban lejátszódó folyamatokkal, mennyiben fedi egymást a két megfigyelés eredménye, milyen erők okozhatják a lehetséges torzulásokat, illetve milyen hatást gyakorol egymásra a két terület.

\section{A Szentgotthárdi Pszichiátriai Betegek Otthona}

A Szentgotthárdi Pszichiátriai Betegek Otthona az Országos Pszichiátriai és Neurológiai Intézet bezárása után Magyarország, és egyben Európa legnagyobb lakószámú bentlakásos pszichiátriai intézete lett 750 fő körüli ellátotti létszámával, és a mai napig is az maradt. (Az elmúlt években több európai uniós pályázat nyílt meg az intézmények kitagolására, átalakítására, azonban a szentgotthárdi intézet egyiken sem tudott részt venni - paradox módon éppen a monumentális mérete miatt -, így jelenleg továbbra sem látható, hogy mikor tud ez a folyamat elindulni.) Ennek megfelelően a pszichiátriai intézmények között méretében, lakószámában szélsőséges esetet reprezentál, amiből azt feltételezem, hogy az itt fellelhető cselekvési lehetőségek, müködésmódok és problémák a szociális intézményrendszer más szegmenseiben is megtalálhatók, csak kevésbé kikristályosodott formában.

A Szentgotthárdi Pszichiátriai Betegek Otthona a Szociális és Gyermekvédelmi Főigazgatóság felügyelete alatt működő bentlakásos pszichiátriai otthon, mely az Emberi Erőforrások Minisztériuma alá tartozik kormányzati szakmai irányítás szempontjából, és bentlakásos otthonként a szociális ellátórendszer részeként funkcionál. A szocializmus alatt zárt intézetként működött, a fövárosból ide „deportáltak” olyan pszichiátriai betegeket, akiket a társadalom számára láthatatlanná akartak tenni, elszakítva őket korábbi társadalmi köze- 
güktöl. Jelenleg az intézetben közel 750 beteg lakik, és több mint 100-an vannak várólistán. Az intézet igazgatója 1982 és 2011 között ugyanaz a személy volt. Az intézmény az ezredfordulótól kezdve lassan nyitott a külvilág felé, és elkezdett progresszív pszichiátriai gyakorlatokat, illetve olyan alternatív terápiás módszereket adaptálni, mint a foglalkoztatásterápia, művészetterápia, vagy a mentálhigiénés foglalkozások. A 2000-es évek elején létrehoztak egy rehabilitációs szemléletủ lakóotthont is, ahol a nagy épületekben való elhelyezéshez képest sokkal humánusabb, emberibb körülmények között élhetnek azok a lakók, akik részleges önellátásra képesek. Itt jelenleg 14 fö elhelyezését tudják biztosítani. A büntetési rezsim lassan veszített totális, büntető jellegéből, egyre inkább átkerült a hangsúly az alternatív terápiák használatára. A 2011-es igazgatóváltással felgyorsultak a modernebb, progresszívebb pszichiátriai kezelési gyakorlat irányba mutató folyamatok. Az igazgatóváltás után másfél évvel, 2013-ban fenntartóváltás következett be, a föváros átadta az államnak a fenntartói jogokat, amiből egyrészt az következett, hogy az intézmény elvesztette autonómiájának egy részét, másrészt lényegesen kevesebb forrással gazdálkodhatott ettől kezdve.

\section{Módszertani megfontolások}

Az esettanulmány létrehozásához több módszertani eszközt használtam párhuzamosan. A kutatás vázát félig strukturált interjúk adják, melyeket terepmegfigyeléssel ötvöztem, illetve különféle, az intézmény működésére vonatkozó jogi anyagot, szabályzatot, vizsgálati anyagot és dokumentumot dolgoztam fel. A kutatás 2016 májusa és szeptembere között zajlott. Az első fázisban pár napot töltöttem a terepen meghívott vendégként, amikor megismerkedtem több, az intézetben dolgozó szakemberrel, és felmértem, milyen előkészületekre lesz szükségem a kutatás megkezdéséhez. A kutatás alatt minden nyári hónapban egy-egy hetet, vagyis összesen közel három hetet töltöttem terepen, amikor egyrészt az intézetben dolgozókkal és a városban lakó más interjúalanyokkal elkészítettem az interjúkat, másrészt terepmegfigyelést végeztem az intézetben, többek között különféle fórumokon, belső megbeszéléseken, értekezleteken, és a betegekkel folytatott konzultációkon. Ezzel párhuzamosan és részben ezt követően, 2016 szeptemberében Budapesten készítettem el az állami szervezetek, a fenntartó, a különféle civil szervezetek és az ombudsmani hivatal munkatársával az interjúkat.

Az interjúkat az intézetben dolgozókkal, illetve az intézménnyel valamilyen hivatalos kapcsolatban álló más intézmények dolgozóival készítettem annak érdekében, hogy a különféle cselekvőhálózatokban fellelhető perspektívákat be tudjam mutatni. Fontos kiemelni, hogy a fenti cél érdekében az adott intézményen belül a hierarchia különböző szintjeiről, másrészt különféle szakmai csoportok képviselöi közül válogattam az interjúalanyokat. Az intézményen belüli dolgozók közül megjelenik a mentálhigiénés csoport, a terápiás csoport, az ápolási-gondozási csoport két hierarchikus szinten is (vezető, osztályvezető, ápoló), a pszichiáterek csoportja, illetve a vezetői csoport. Az intézményen kívüli megkérdezettek között az alábbi szervezetek találhatóak: Szentgotthárdi Rendőrkapitányság; Szociális és Gyermekvédelmi Főigazgatóság (SZGYF), mely 2013 óta a az intézet fenntartója; az Emberi Erőforrások Minisztériuma (EMMI), mely minisztérium az egész szociális ellátórendszer kormányzati irányító szerve; illetve az Alapvető Jogok Biztosának Hivatala (AJBH, ombudsman), mely hivatal az elmúlt években több emberi jogi fókuszú jelentésben foglalkozott a Szentgotthárdi Pszichiátriai Betegek Otthonával és tett ajánlásokat számára. 
Az interjúk elemzésénél a releváns narratív részleteket feldolgozva a modernitáselméletekből kialakított dimenziók mentén elemeztem az interjúkat, és az így kapott eredményekből az intézet egészének müködésére nézve vontam le következtetéseket. A narratív részleteket dimenziónként 15-25 oldalas Excel táblázatokban rögzítettem, aldimenziónként és cselekvői perspektívánként szétbontottam, majd ez alapján készítettem el az elemzést. A kutatás során összesen 25 interjú készült, melyből 12 interjút használtam fel a kutatás ezen fázisában.

Az interjúkat kiegészítettem az intézet működését érintő dokumentumok, működési szabályzatok, szakmai anyagok, vizsgálatok anyagainak feldolgozásával, illetve terepen történő megfigyeléssel. A feldolgozott dokumentumok között az alábbiak szerepelnek: Szervezeti és Működési Szabályzat (SZMSZ), Házirendek, Közösségi Konfliktus- és Bünmegelőzési Stratégia (továbbiakban: Bünmegelőzési Stratégia), szakmai programok; 1/2000 SZMCS-rendelet; levelezések; a gondozási részleg beszámolója; az ombudsmani vizsgálat beszámolói; Fönix-program; prezentációk; és Kapócs Gábor intézményvezetői pályázata.

A kutatás szempontjából két körülményt érdemes megemlíteni. Az intézethez a kutatást megelözően csupán egy ott dolgozó szakemberen keresztül volt személyes kapcsolatom, ezért kérdéses volt, hogy milyen mélységben tudok eljutni az interjúalanyokhoz. Azonban sikerült a kutatás korai fázisában sokféle intézeten belül dolgozó emberrel megismerkednem, és rajtuk keresztül gyorsan eljutottam minden olyan fontos cselekvői szerepet reprezentáló egyénhez, akikkel a kutatás megtervezésének fázisában szerettem volna interjút készíteni. Szubjektív megítélésem szerint az interjúalanyok és az intézeti dolgozók nyitottak, elfogadóak voltak az irányomba, és mivel nem csak az interjúk készítésekor találkoztam velük, hanem folyamatosan részt vettem a mindennapi munkájukban, sőt munkaidőn túl is megfigyelhettem a tevékenységüket, összejöveteleiket, azt gondolom, hogy a szokásos interjúkon alapuló esettanulmányoknál mélyebb betekintést kaphattam az intézet életébe. Másfelöl érdemes megemlíteni azt a körülményt is, hogy a kutatás kezdete után nem sokkal derült ki, hogy az akkor regnáló igazgató nem tudja újból megpályázni az igazgatói helyet a jogszabályok módosulása miatt, ezért a kutatás középső fázisában volt a számukra is felkavaró, az ott dolgozókat nagymértékben foglalkoztató pályázati szakasz, aminek következtében mindennapi téma volt az intézet müködésének és vezetésének értékelése. Ez számomra annyiban szerencsésnek is volt mondható, hogy többen maguktól tértek ki olyan részletekre a múltból, amikre valószínüleg nem emlékeztek volna, vagy nem tartották volna őket említésre méltónak, ha a mindennapi beszélgetéseikben nem idézték volna fel ezeket egymás között, köszönhetően a helyzetnek.

\section{Az esettanulmány}

Az elemzést két szinten végeztem, egyrészt az egyes dimenziókban megvizsgáltam az aktuálisan fennálló helyzetet és változásokat, másrészt ezeket az eredményeket aggregáltam, és az egész intézmény müködésére nézve vontam le belőlük következtetéseket. Az intézményt vizsgálva összességében az látszik, hogy a rendszerváltás után ugyan lassan, de elindult egy nyitási folyamat a külvilág felé mind a kommunikáció, mind a müködésmód tekintetében. A változások a 2011-es igazgatóváltással gyorsultak fel igazán. A cselekvőkkel folytatott kommunikáció dimenziójában észlelhető, hogy az intézmény elkezdett nyitni a különféle külső 
cselekvők és a nyilvánosság irányába, sok területen olyan kommunikációs csatornákat épített ki a külvilág felé, melyek elősegítették a reflexió kialakulását. Az olyan intézményekkel, melyekkel egyenrangú kapcsolatban állt az intézmény, kétoldalú, partneri kapcsolatokat alakítottak ki. Ezek egyfelől elősegítették az információk áramlását, másfelöl megkönnyítették a különféle konfliktusos helyzetek egyszerübb rendezését, mivel nem kizárólag a lassú, időigényes bürokratikus utat vették igénybe, hanem informálisan, személyes kapcsolatokon keresztül is kommunikáltak egymással. Az intézet vezetőségi tagja így fogalmazza ezt meg például a rendőrséggel kialakított kapcsolatról:

Az igazgató úrnak is köszönhetően, hogy ezt a kapcsolatot elősegítették, és szorosabbra tudták füzni, nekünk ez sokat jelen. Azért látjuk a segítőkészséget és az együttmüködést az ő részükről is. Bejöttek már az intézménybe, fórumokat tartottak a lakóinknak, és már kinti normaszegések, vagy olyan magatartások után is segítenek, bekísérik a lakóinkat, megjelennek.

A rendőrkapitány pedig így látja ezt:

Próbált az intézmény nyitottabb lenni. Eddig se volt zárt intézet, hanem olyan szinten próbál nyitott lenni az intézet, hogy megismertetik a városlakókkal az ottani munkát, az ott élő embereket. Megmutatják, hogy ezek között a betegek között is mennyi értékes ember van.

Az Alapvető Emberi Jogok Biztosa hivatalának munkatársa is beszámol a változásokról abból az időszakból, amikor az ombudsman kritikát fogalmazott meg az intézmény működésével kapcsolatban: „...akkor már szerencsénk volt, mert volt egy olyan kommunikáció a vezetővel, hogy látszott és tudtuk, hogy meg akarja oldani”. Emellett az érdekvédő szervezetek és a nyilvánosság felé is nyitottak, ami azt jelentette, hogy nem csak formálisan fogadták el a kritikákat, hanem azokra valós intézkedésekkel reagáltak. Amikor konkrét problémák merültek fel, olyan megoldásokat igyekeztek keresni, melyek nem csak tüneti kezelést jelentettek, hanem rendszerszinten okoztak változásokat. Jó példa erre a Közösségi Konfliktus- és Bünmegelőzési Stratégia, ami az ombudsmani panasz nyomán jött létre hosszú egyeztetési folyamatot és belső munkát követően. Ez a stratégia nem csak azokon a területeken alakította át a büntetési rezsim müködését, ahol kritika érte, hanem preventív jelleggel az egész struktúrát újraszabta, előtérbe helyezve a resztoratív (jóvátételi, helyreállító) szemléletmódot. Az ombudsman utánkövető vizsgálata az alábbiaknak megfelelően rögzítette a pozitív változásokat:

A 2004-ben létrehozott és az előzményügyben is kifogásolt Speciális Részleg müködtetése 2012. március 1-jével megszűnt, helyén a pszichoterápiás csoport rehabilitációs foglalkozásainak helyet adó, csoportos és egyéni foglalkoztató szobákat alakítottak ki, melyek átalakítása, berendezése a helyszíni vizsgálat idején folyamatban volt (lásd: AJB-228/2010. számú jelentés). Tájékoztattak arról, hogy a Speciális Részlegre való elzárás helyett „,esetvezetési team”-eket alakítottak, amelyekben szakértő segítők, ápolók és orvosok, a beteg(ek) bevonásával, együttmüködésben kerestek (és zömmel találtak, találnak is) megoldásokat azokra a problémákra, melyek „megoldását”, kezelését korábban az elzárás jelentette. A dolgozók többsége örömmel nyugtázza a Speciális Részleg megszűnését, tapasztalataik szerint ez egyrészt a lakókkal való kapcsolataikban is pozitív változást eredményezett, másrészt a helyette alkalmazott pszichoterápiás eszközök (munka- és/vagy művészetterápiás foglalkozások) a betegek állapotára is lényegesen jobb hatással vannak (AJBH 2012: AJB-457/2012). 
Azt azonban érdemes megjegyezni, hogy az idő előrehaladtával bizonyos visszarendeződési folyamatok elindultak ezen a téren. Kudarcosnak egyedül a fenntartóval való kapcsolatukat lehet nevezni. Az intézmény ezen a területen is igyekezett konstruktívan kezelni a fenntartó felöl érkező kéréseket, de több esetben kudarcot vallottak a fenntartó elzárkózó magatartása miatt. Mivel hierarchikusan alárendelt az intézmény a fenntartónak, nincs nagy cselekvési tere vele szemben, ezért sok probléma nem, vagy csak részlegesen oldódott meg. Az intézet egyik vezetőségi tagja így önti ezt szavakba:

Inkább informális a közvetlen érintkezés, mert a szolgálati utat be kell tartani, tehát elöször a megye, és a megye továbbít mindent. Tehát mi közvetlenül egy levelet nem küldhetünk el Budapestre, hanem először Szombathely, aztán onnan oda. Csak apró döntéseket tudunk hozni, amik ilyen napi szintű döntések, de nagyobb döntésekbe már nem volt beleszólásunk. Az idén például nem írták alá az SZMSZ-ünket. Eddig ilyen nem volt, hogy visszadobták volna az SZMSZ-t. Most visszadobták, és nem tudjuk, hogy mi a cél. Majd ők megmondják, hogy mit csinálhatunk? Ez így a napi feladatokat is hátráltatja, mert szeretnénk aszerint dolgozni, de nem tudunk.

A reflexív szervezeti forma dimenziójában az elöző dimenzió dinamikájához hasonló tendenciát találtam. Az intézmény korábban zárt, erősen hierarchikus, patriarchális, centralizált szervezet volt. Az új igazgató érkezése után ezen a téren is változások indultak el. Az egyik szakmai csoport vezetője meséli a lakók érdekérvényesítési fórumairól:

Ez egy ilyen közös kommunikáció, ami elég interaktív módon történik, tehát a lakók beszélnek, aztán megkapják a megfelelő válaszokat. Tehát ez egy ilyen közös beszélgetésen zajlik, aminek nagyon fontos eleme, hogy feljegyzés készül róla, és írásos nyoma is van.

A lakók estében továbbra is fennmaradt az erősen alá-fölé rendelt, kiszolgáltatott viszony, de a korábbiakhoz képest pozitív elmozdulást lehet érzékelni azon a téren, hogy a büntetési rendszer átalakulásával a normaszegő lakók sorsáról nem a pszichiáter dönt egy személyben, hanem terápiás szerződés keretében a betegek választhatnak bizonyos büntetési formák közül, illetve csökkent a velük szembeni önkény. Emellett azonban sok jel mutat arra, hogy a lakók továbbra is alárendelt pozícióban vannak a dolgozókhoz képest. Erre említhető példaként a fehér köpeny viselése, a pszichiáterek egy részének egyoldalú és paternalisztikus kommunikációja a lakókkal, ami betegkórtermi viziteken, vagy akár folyosón elcsípett beszélgetésekben tetten érhető volt, vagy a külön pihenő- és étkezőterek használata. A lakók számára elérhető érdekvédelmi fórumok elég aktívnak tűntek, de az nem derült ki a kutatás során, hogy a lakók ezeken keresztül mennyire képesek az érdekeiket érvényesíteni.

A lakókhoz képest a dolgozók estében markánsabb változások figyelhetők meg. Az új igazgató egy teljesen új szervezeti müködési modellt próbált meghonosítani az intézményben. Ennek az új modellnek a legfőbb jellemzői a dolgozókkal való közvetlenebb kommunikáció, a teammunka és a demokratikus fórumok kialakítása, a hierarchikus szervezeti modell fellazítása, illetve a hagyományos autoritások, mint például a pszichiáterek kizárólagos hatalmának megkérdőjelezése bizonyos területeken. Az egyik pszichiáter szavaival:

Tény, hogy itt is van egy lenyomata annak, ami az egészségügyben zajlik, tehát hogy az orvosi hierarchiának, meg dominanciának... föleg volt, meg van is, ez így a régebbi idökre visszanyúlva volt egy ilyen hierarchia is felépítve, hogy ki a föorvos, és kinek van a végső szava ezekben a döntésekben. Az, amit most látsz, és valamennyire működik, hogy egy kicsit csapatközpontú ez 
az ellátás, és hogy megpróbálja mindenki a sajátját beletenni, és ebből egy kompromisszumos megoldásra jutni, azért ez nem egy olyan régi keletű... Egyértelmű, hogy azoknak lehet ez jó, akiknek kompetens véleményük van, és akiket eddig nem hallgattak meg. (...)

Máshol a terápiás csoport egyik tagja így mesél erröl:

Nálunk nincsenek meg a jogi keretei a teammunkának. Ebből kifolyólag... ami hát, nem jó, viszont korábban, mivel az igazgató ezt fontosnak tartotta, (...) valamennyire mégis sikerült korlátokat szabni a pszichiátereknek, és valamennyire el is fogadták ezt.

Az érdekvédelmi fórumok közül ebben az időszakban a Közalkalmazotti Tanács (KAT) megerősödött, sokkal több jogkörrel és agilisabb vezető irányításával végezte a munkáját, mint korábban. A KAT viszonya mind a dolgozókkal, mint az intézményvezetéssel kifejezetten jó volt, így alkalmassá vált arra, hogy a problémákat, kritikákat, változtatási javaslatokat becsatornázza a vezetés irányába. A KAT elnökének szavaival:

Ezeket a problémákat összeírogattuk, majd leültünk az intézet vezetésével, és mondtuk, hogy mi azért ezekkel a jogokkal szeretnénk élni. Nem is volt ellenvetésük, igazgató úr támogatott minket mindenben, és akkor így átalakult ez az egész rendszer, és azóta így bele is szólogatunk dolgokba.

A dolgozók szavaiból érződött, hogy a változásokkal szemben még sokan bizalmatlanok voltak, és nem internalizálták az új működési modell alapelveit, így nem lehet tudni, hogy hoszszabb távon mennyire lenne tartós az új modell, ha például az intézet vezetése megváltozna. Ebben a dimenzióban azt mondhatjuk, hogy alapvetően emancipatorikus irányba mozdult el az intézmény müködése, azzal együtt, hogy sok helyen még időről időre patologikus reakciók is felszínre törnek, és nem lehet biztosan látni, hogy a reflexivitás kis szigetei mennyire tudnak tartósak maradni.

A reflexív cselekvési tér kiszámithatóságának dimenziójában azt találtam, hogy a rendszerváltás előtti reflexivitást gátló tényezők nem tüntek el nyomtalanul, nem sikerült 25 év alatt sem felszámolni őket. A legerősebb torzító hatást a szociális szféra anomáliái, illetve ezen belül a fenntartó működése okozzák. Sok esetben érződik, hogy az intézmény szeretné kihasználni a reflexív potenciálját, szakmai fejlődési lehetőségeit, vagy innovatív megoldásokat vezetne be, azonban ezek rendre megbuknak a nagyobb ágazati struktúra hiányosságain és kommunikációképtelenségén. Az ombudsmani hivatal munkatársa szerint:

Szűkek a lehetőségek az egész szociális szakmában, de ez most egy másik kérdés. Ez egy másik dolgozat témája lehetne, hogy milyen őrületes módon összefügg a rendszer, és hogy mennyire nem szabadna ezt az egész szakmát ennyire margóra helyezni, mert hiszen rajtuk múlik, hogy hogyan tud müködni egy ilyen intézmény, hogy milyen változások mennek át, még ha csak az állami fenntartású pénzek is csak csöpögnek, és még ha csak nagyon kevés is jut, mégiscsak tud emberi lenni egy jó szociális team. És igazából a még ott dolgozók hihetetlen erőfeszítésén múlik, hogy tud-e jól müködni a rendszer, vagy sem.

Mivel az intézmény hierarchikusan erősen alárendelt és kiszolgáltatott ennek a mezőnek, nem sok mozgástere marad, ha változtatni szeretne, csak a saját erőforrásaiból tud gazdálkodni. Az intézmény azóta van hierarchikusan különösen alárendelt pozícióban, mióta fövárosi fenntartásból átkerült állami fenntartásba, a maradék gazdasági és szakmai autonómiáját is elveszítette. Erről az alábbiakat mondja a vezetőség egyik tagja: 
Viszont azzal, hogy nem vagyunk önállóak, és egyre inkább nem vagyunk önállóak, egyre inkább úgy érzem, függünk az Szociális és Gyermekvédelmi Főfelügyelőségtől (SZGFY), először is a megyei kirendeltségtől, másrészt a budapesti SZGYF központtól. És ezek azért nehézséget jelentenek itt. Egyrészt a gazdálkodási részen, másrészt az együttműködésnek a befolyásolása.

Egy másik helyen így fogalmaz az egyik osztályvezető:

Igen, az elején, amikor az államosítás elindult, akkor ez még annyira nem volt érezhető, és ezt fokozatosan érezzük. Most már egyre több mindenbe beleszólnak. Az, hogy mindenért engedélyt kérni, mindent egyeztetni, mielőtt bármit teszünk. Vagy több vizsgálatot kezdeményeznek...

Ezek a torzító hatások kiegészülhetnek a jogi környezet rugalmatlanságával, ami egyes esetekben teljesen be tudja fagyasztani a változásokat, és az intézményt rugalmatlanná teszi. A fenti területek mellett jelentős torzító hatást gyakorol a politika is az intézmény müködésére, de ez a hatás nem olyan állandó, mint a szociális szféra és a fenntartó hatása, ezért jelentőségében is jóval kisebb. Sokak szerint a kormányzati szándék hiánya tehető felelőssé azért, hogy a szociális ágazatban, és ezen belül különösen a pszichiátriai intézményrendszer területén stagnálás van finanszírozási és szakmai értelemben is. A mentálhigiénés csoport egyik tagjának véleménye szerint:

$\mathrm{Az}$, hogy ennek mi az oka, valószínüleg kormányzati dolgok is vannak a háttérben, politikai irányváltások, tehát nem az intézmény tehet erről, hogy elkezdtünk most ilyen szép lassú leépülés felé haladni.

A szerkezeti problémák közül a veszélyeztető állapotú betegek elhelyezésének ügyével kapcsolatban többen, többek között a terápiás csoport egyik tagja, számoltak be arról, hogy a kormányzat nemhogy nem segítő szándékkal lépett fel, hanem inkább hátráltatta a folyamatokat, más, az intézményrendszer működésétől független politikai érdekek mentén:

Európában csak nálunk nincsen ilyen osztály. Ezt norvég pénzből hozták volna rétre, aztán nem hozták létre, mert összevesztünk a norvégokkal. Ez akkor hiúsult meg, de egyébként most lehet, hogy valamikor létre fogják hozni, de valószínűleg ezt is úgy, hogy kevés férőhellyel.

A rendszer tehetetlensége ugyan több területen jelentkezik, mint lehetséges torzító hatás, de csupán más hatásokkal kölcsönhatásban, így nem mondhatjuk, hogy önmagában torzítja az intézmény müködését. Az AJBH munkatársa, mások véleményével összhangban, a rendszer tehetetlenségének okát például abban látta, hogy:

...ha egy vidéki kisvárosnak a legnagyobb nappali munkaadója egy intézmény, akkor miért akarna újítani. Igazából nagyon sok a kontraindikáció, nagyon sok az olyan helyzet, ami nem teszi könnyüvé azt, hogy valóban egy 21. századi és ezeknek az új emberjogi paradigmáknak megfelelő intézmény csak úgy tudjon müködni.

Többen hangot is adtak annak a félelmüknek, hogy a rendszer visszarendeződésétől tartanak. Az egyik pszichiáter véleménye szerint:

Azért vannak próbálkozásai a régi rendszernek a visszatérésre. Tehát nehéz ezt így csinálni és müvelni. Folyamatosan figyelni kell, hogy a változások tartósak maradjanak. (...) Tehát amit szokott mondani Kapócs Gábor (az igazgató), ez teljesen igaz, hogy nagyon tehetetlen ez a rendszer, és hogy ezen egy pici változás nagyon hamar vissza tud alakulni, ha nem figyelünk erre. Ezt láttuk is. 
Az intézet egyik vezetője ehhez az alábbiakat füzi hozzá:

Nehéz, bár az élesztőből kevés kell, állítólag (nevet), de valamennyi azért kell. Egy kiló liszthez azért egy élesztő kell körülbelül. Egy kicsit kevésnek tűnik most ez, amennyi élesztő van enynyi tésztához. Ebben benne van az, hogy nagyon monumentális ez az intézet, és akkor, ahogy müködött, ez nagyon be van állva, és hogy ezt lehet nagyon bolygatni. Kevesen vagyunk, meg a félelem. Egy csomó dolog miatt, de hogy valahogy kicsit kevés most ez a szemlélet.

Összességében elmondható, hogy a különféle torzító hatások ereje elég nagy ahhoz, hogy befolyást gyakorolhassanak arra, hogy a cselekvők mennyire érzik kiszámíthatónak, autonómnak, cselekvőképesnek az intézményt, ez pedig az intézmény reflexív cselekvési potenciáljába vetett hitet rombolja a cselekvőkben, ami végső soron patologikus hatást gyakorolhat az egyének és az intézmény dialogikus viszonyára. A reformok, progresszív gyakorlatok dimenziójának vizsgálatakor azt figyeltem meg, hogy a legtöbb reformkísérlet az új igazgató nevéhez füződik. Ezek a reformok főként az igazgató hatására, részben pedig olyan külső tényezők hatására indultak el, mint az ombudsmani jelentés. A kutatásból kirajzolódó kép azt mutatja, hogy az igazgatóváltás után a teljes paradigmaváltás irányába mozdult el az intézmény egy erőskezű vezető víziója mentén. A változások egyszerre érintettek több területet, úgymint: belső müködési szabályok, szervezeti kultúra, oktatás, pszichiátriai kezelési gyakorlat, alternatív terápiák, de említhetjük az intézménytelenítési terveket is. Az EMMI munkatársa ezt meséli erről:

Rengeteget változott az intézet. Elöször is lett lakóotthonuk. A foglalkoztatásban egy csomó új dolgot behoztak a művészetterápián kívül. Megpróbálták differenciálni az ellátásukat, térben is, meg tartalmilag is, elválasztani, ami inkább egészségügyi ellátás, és egy másik épületbe, a demenseket egy épületbe rakták. Ök szakmailag folyamatosan új utakat keresnek.

Az intézet igazgatóhelyettese pedig a következőket osztotta meg az orvosi szemlélet változásáról:

És igazából a gyógyszercsökkentés Sebestyén doktor (az egyik pszichiáter) belépése után indult, ő azzal, hogy fiatal, új szemléletet hozott az orvoslásba is, a pszichiátriába, és mellette akut osztályon is dolgozik, tehát ő hozza mindig a friss dolgokat.

Az elmúlt öt év távlatában látszik, hogy a paradigmaváltási kísérlet nem vezetett sikerre. A reformok jó részét sikerült valamilyen módon elindítani, azonban mind a belső, mind a külső erők sok esetben ellenük dolgoztak, így vagy el sem tudtak kezdődni, mint a kitagolás; vagy csak részben valósultak meg, mint a Közösségi Konfliktus- és Bünmegelőzési Stratégia bevezetése; vagy a dolgozók többsége elutasítja és részben szabotálja őket, mint a progreszszív pszichiátriai terápiás és gyógyszerezési gyakorlatot vagy a teammunkát. Az interjúkból például kiderül, hogy míg a Közösségi Konfliktus- és Bűnmegelőzési Stratégia előír egyfajta progresszívebb, resztoratív (jóvátételi, helyreállító) szemléletű szankcionálási gyakorlatot, mint ami korábban volt, ez a gyakorlatban egyre kevésbé valósul meg. Az intézet kriminológusának szavaival:

Ebben például sikerült eredményeket elérni, de most ez is olyan gyakorlat, ami automatizmussá vált, és ami nem teljesen felel meg a stratégia szemléletének. Tehát a stratégia nem azt mondja, hogy minden egyes ilyen normaszegésnél rögtön meg kell vonni két hétre a kimenőt, hanem 
mérlegelés kérdése, hogy kell-e, illetve a két hét sem fix, lehet két hétnél kevesebb, illetve lehetne helyette a jóvátételi munkát használni. Na most ezek mind kiestek, és automatikussá váltak ezek a kéthetes büntetések. De pozitívuma, hogy legalább csak két hét, és nem mondjuk 3 hónap, mint régen.

Ebből arra következtethetünk, hogy míg a felszínen rugalmasnak és progresszióra képesnek tűnik az intézmény, a felszín alatt sok esetben igyekszik megóvni a tradicionális szakértői tudásokat a külső kritikákkal, hatásokkal szemben, müködése pedig sok helyen merev és rugalmatlan maradt.

\section{Az eredmények összegzése}

Összefoglalva, kutatásomban azt találtam, hogy a reflexivitás feltételei bizonyos korlátokon belül teret tudnak nyerni az intézmény müködésében, de rendszerszinten csak a felszínen válnak a mindennapi gyakorlatok részéve, a mélyebb rétegeket személve nagyon sok a bizonytalanság. A reflexív intézményi logika egyre több területen gyökeret vert az intézményben, különösképpen az új igazgató regnálása idején, ami azt mutatja, hogy a jogi-szabályozási környezet ugyan nem tiltja, de nem is ambicionálja ezen formák megjelenését, sokkal inkább az adott vezető személyes szándékain múlik, hogy elindul-e a változás. Mivel a rendszernek nem inherens jellemzője a reflexivitásra törekvés, gyakran visszarendeződés figyelhető meg abban az esetben, ha a személyi feltételek megváltoznak vagy más szférák logikája eltéríti az intézményi működés irányát. A reflexív logika tehát megjelenik ugyan, de nem tud stabil cselekvéskoordinációs elvvé válni. Mivel hazánkban az egyéni cselekvők nagy része szocializációja során nem tud olyan képességeket elsajátítani, melyek stabilan képessé tennék reflexív cselekvések kialakítására, a civil érdekérvényesítő szféra ereje történelmi és politikai okok miatt igen csekély, az intézmények pedig sok szempontból más szférák és érdekek foglyai. Bizonyos, hogy ha lenne szándék rá, akkor komplex irányból lehetne hozzáfogni a rendszer átalakításához annak érdekében, hogy az ilyen típusú intézmények jobban tudjanak alkalmazkodni a megváltozott társadalmi feltételekhez, a reflexivitás terei megnyílhassanak, müködésükben az emancipatorikus válaszok kerülhessenek túlsúlyba, és ne patologikus tendenciákat erősítsenek fel társadalmi szinten.

\section{Hivatkozott irodalom}

Alapvető Jogok Biztosának Hivatala (2010): „Méltóképpen Másképp” - fogyatékosügyi projekt. ÁJOB projektfüzetek 2010/2. Interneten: https://www.ajbh.hu/documents/10180/124840/fogyatekosugyi.pdf (letöltve: 2018. május 1.).

Arató Krisztina és Nizák Péter (2012): Az érdekérvényesítéssel foglalkozó civil szervezetek társadalmi beágyazódottsága Magyarországon. Civil Szemle 9(2): 5-25.

Bányai Borbála és Légmán Anna (2009): Pszichiátriai betegek szociális intézeti környezetben. Esély 20(2): 68-84. Interneten: http://www.esely.org/kiadvanyok/2009_2/004BANYAY.pdf.

Bányai Borbála és Légmán Anna (2009): Az állam szerepének változásai a pszichiátriai ellátórendszerben. Tanulmány a Magyar Szociológiai Társaság konferenciájára. Interneten: http://www.szociologia.hu/dynamic/ BanyaiB_LegmanA_MSZT_konf_2009_tanulmany.doc (letöltve: 2017. november 15.).

Beck, Ulrich (2003 [1986]): A kockázat-társadalom. Út egy másik modernitásba. Budapest: Századvég - Andorka Rudolf Társadalomtudományi Társaság. 
Boda Zsolt és Medve Bálint (2012): Intézményi bizalom a régi és az új demokráciákban. Politikatudományi Szemle 21(2): 27-51.

Boltanski, Luc és Thévenot, Laurent (2008 [1999]): A kritikai képesség szociológiája. Replika (62): 39-55. Interneten: http://replika.hu/replika/62-03.

Boltanski, Luc és Chiapello, E (1999): Le nouvel esprit du capitalisme. Paris: Gallimard.

Castells, Manuel (1996): The Rise of the Network Society. Oxford: Blackwell Publishers. DOI: https://doi. org/10.1002/9781444319514.

Dubet, François (2002): Le Déclin de l'institution. Paris: Seuil.

Engel, George (1977): The Need for a New Medical Model. A Challenge for Biomedicine. Science 196(4286): $129-136$. DOI: https://doi.org/10.1126/science.847460.

Erving, Goffmann (1974 [1961]): Asylums. Essays on the Social Situation of Mental Patients and Other. Reprint. Harmondsworth: Penguin Books. DOI: https://doi.org/10.4324/9781351327763.

Foucault, Michel (2004 [1972]): A bolondság története. Budapest: Atlantisz.

Foucault, Michel (2014 [1974-1975]): A rendellenesek. Budapest: L'Harmattan.

Giddens, Anthony (1990): The Consequences of Modernity. Cambridge: Polity.

Giddens, Anthony (1984): The Constitution of Society. Outline of the Theory of Structuration. University of California Press.

Giddens, Anthony (2013 [1991]): A késő modernitás körvonalai. Replika (82): 113-130. Interneten: http://replika. $\mathrm{hu} / \mathrm{replika/82-06.}$

Giddens, Anthony (2013 [1994]): Élet a poszttradícionális társadalmakban. Replika (82). Interneten: http://replika. hu/replika/82-04.

Giddens, Anthony (1995): Beyond Left and Right. The Future of Radical Politics. Cambridge: Polity.

Giddens Anthony (1991): Modernity and Self-Identity. Self and Society in The Late Modern Age. Cambridge: Polity.

Hámornik Balázs Péter, Juhász Márta és Vén Ildikó (2015): Kommunikációs mintázatok vizsgálata az orvosi rehabilitációs teammunkában. Alkalmazott Pszichológia 15(3): 55-78.

Kolosi Tamás, Szelényi Iván, Szelényi Szonja és Bruce Western (1991): Politikai mezők a posztkommunista átmenet korszakában. Pártok és osztályok a magyar politikában (1989-1990). Szociológiai Szemle 1(1): 5-34. Interneten: http://www.szociologia.hu/dynamic/9101kolosi.htm.

Légmán Anna (2011): Az őrület és az őrültek helye a társadalomban. (Doktori disszertáció.) Pécs: PTE BTK. Interneten: http://pea.lib.pte.hu/bitstream/handle/pea/14758/legman-anna-phd-2012.pdf (letöltve: 2018. május 1.).

Légmán Anna (2011): Állandóság vagy átalakulás? A magyar pszichiátriai ellátórendszerről. Replika (74): $169-185$. Interneten: http://replika.hu/replika/74-08.

Málovics Éva, Vajda Beáta és Kuba Péter (2009): Paternalizmus vagy közös döntés? Páciensek az orvos beteg kommunikációról. In A szolgáltatások világa. Hetesi Erzsébet, Majó Zoltán és Lukovics Miklós (szerk.). Szeged: JATE Press, 250-264.

Memmi, Dominique (2012 [2004]): Egy érzékeny terület igazgatása. Ésszerű magatartás és test általi felügyelet a születés és halál kapcsán. Replika (79): 77-89. Interneten: http://replika.hu/replika/79-05.

Ozsváth Károly (2012): Paradigmaváltások az elmegyógyászatban. Pécs: PTE. Interneten: http://psychiatry.pote.hu/ html/ozsvath_paradigma.html (letöltve: 2018. május 1.).

Sik Domonkos (2013): Giddens modernizációelmélete. Intézményi átalakulás és politikai praxis. Replika (82): 97-112. Interneten: http://replika.hu/replika/82-05.

Sik Domonkos (2015): Klasszikus és késő modernitás a rendszerváltás utáni Magyarországon. Socio.hu 5(1): 246-276. DOI: https://doi.org/10.18030/socio.hu.2015.1.246.

Sik Domonkos (2012): A modernizáció ingája. Budapest: ELTE Eötvös Kiadó.

Szalai András (2011): Ideák, politika és intézmények: a politikatudomány három „új institucionalizmusa”. Repli$k a$ (74): 35-62. Interneten: http://replika.hu/replika/74-03.

Paul J. DiMaggio és Walter W. Powell (2011): Új intézményi megközelítés a szervezetelméletben. Replika (74): 63-95. Interneten: http://replika.hu/replika/74-04.

Pikó Bettina (2002): Adalékok a mentális zavarok kritikai szociológiájához. Szociológiai Szemle 12(2): 99-113. Interneten: http://www.szociologia.hu/dynamic/0202piko.htm.

Rényi Ágnes, Sík Domonkos és Takács Erzsébet (2014): Elemzési szempontok a késő modern társadalmak kordiagnózisához. Szociológiai Szemle 24(3): 18-60. Interneten: http://www.szociologia.hu/dynamic/renyi_et_al.pdf.

Takács Flóra (2017): Esettanulmány - egy határszéli pszichiátriai intézet válaszai a késő-modern társadalmi kor kihívásaira. (Szakdolgozat.) Budapest: ELTE TáTK. Interneten: https://www.academia.edu/36545177/Egy_határszéli_pszichiátriai_intézet_válaszai_a_késő-modern_társadalmi_kor_kihívásaira_szakdolgozat_ELTE_TáTK_.doc (letöltve: 2018. május 1.). 


\section{Egyéb dokumentumok}

Közösségi konfliktus- és Bűnmegelőzési Stratégia - Szentgotthárd (2015)

Az Alapvető Jogok Biztosának jelentései:

AJB-228/2010. számú ügy

AJB-672/2011.számú ügy

AJB-4350/2012. számú ügy

AJB-457/2012.számú ügy

AJB-4464/2014. számú ügy 